\title{
PREVENTION OF HETEROTOPIC OSSIFICATION AFTER TOTAL HIP REPLACEMENT
}

\author{
A PROSPECTIVE, RANDOMISED STUDY USING ACETYLSALICYLIC ACID, \\ INDOMETHACIN AND FRACTIONAL OR SINGLE-DOSE IRRADIATION
}

D. KNELLES, T. BARTHEL, A. KARRER, U. KRAUS, J. EULERT, O. KÖLBL

From the University of Würzburg, Germany

We have carried out a prospective, randomised study of prophylaxis for heterotopic ossification (HO) comparing indomethacin for 7 and 14 days, acetylsalicylic acid, and fractional $(4 \times 3 \mathrm{~Gy})$ or single exposure of 5 or $7 \mathrm{~Gy}$ irradiation after operation.

We initially had 723 patients (733 hip replacements), but after withdrawals there were 685 hips of which $18.4 \%$ developed HO; $14 \%$ were grade I, $2.9 \%$ grade II and $1.5 \%$ grade III of the Brooker classification.

We compared the results between these groups with those of a matched control series and found that indomethacin, $2 \times 50 \mathrm{mg}$ for 7 and 14 days, and postoperative irradiation of $4 \times 3 \mathrm{~Gy}$ or $1 \times 7 \mathrm{~Gy}$, significantly reduced the development of $\mathrm{HO}$ compared with the control group. Patients in the acetylsalicylic acid group and those with a single irradiation of $5 \mathrm{~Gy}$ after operation developed significantly more ossification than those in the indomethacin and other irradiation groups.

We suggest the use of $2 \times 50 \mathrm{mg}$ of indomethacin with mucoprotection for seven days as prophylaxis against $\mathrm{HO}$ after total hip replacement for all patients. A single irradiation of $7 \mathbf{G y}$ is recommended for patients who have developed HO after previous operations or to whom administration of indomethacin is contraindicated.

J Bone Joint Surg [Br] 1997;79-B:596-602.

Received 12 April 1996; Accepted after revision 24 February 1997

D. Knelles, MD

T. Barthel, MD

A. Karrer

U. Krause

J. Eulert, MD, Professor and Head of Department

Department of Orthopaedic Surgery, Julius-Maximilians-University of Würzburg, König-Ludwig Haus, Brettreichstrasse 11-13, D-97074 Würzburg, Germany.

O. Kölbl, MD

Department of Radiation Therapy, Julius-Maximilians-University of

Würzburg, Josef-Schneider-Strasse, D-97080 Würzburg, Germany.

Correspondence should be sent to Dr D. Knelles.

C)1997 British Editorial Society of Bone and Joint Surgery 0301-620X/97/46829\$2.00
Heterotopic ossification ( $\mathrm{HO}$ ) is atypical bone formation occurring in muscle and connective tissue, and differs from calcification in terms of its osteoblastic activity. ${ }^{1,2}$ Nollen and Slooff $^{3}$ and Jowsey ${ }^{1}$ suggested that undifferentiated mesenchymal cells differentiate to osteoblasts and produce osteoid which is mineralised to become bone. Friedenstein ${ }^{4}$ and Owen ${ }^{5,6}$ postulated the existence of two types of precursor cell in periarticular tissue at the hip. The first is determined osteogenic progenitor cells (DOPC) which originate in stromal parent cells of the bone marrow and after contact with non-resident tissue develop into osteoblasts. The second type is inducible osteogenic progenitor cells (IOPC) which are found in periarticular soft tissue and migrating and circulating in the blood stream. These need bone morphogenetic protein (BMP) to develop into osteoblasts.

The use of non-steroidal anti-inflammatory drugs (NSAIDs) for prophylaxis against HO is credited to Dahl ${ }^{7}$ who carried out a study on 39 patients using indomethacin (Table I). Since then, many prospective and retrospective clinical studies have been carried out using NSAIDs; these differ in the drugs used and the length of treatment. Indomethacin, ibuprofen, acetylsalicylic acid and diclofenac have all been investigated. In 1981 Coventry and Scanlon ${ }^{8}$ showed the efficacy of postoperative irradiation in preventing $\mathrm{HO}$ after total hip replacement in 48 high-risk patients using ten doses of $2 \mathrm{~Gy}$. There have been many other studies carried out exclusively on high-risk patients, at first using divided doses up to $20 \mathrm{~Gy}$ but later reducing to $10 \mathrm{~Gy}$. More recently, single doses of irradiation have been used after operation. Lo et al $^{9}$ used 7 Gy and Hedley, Mead and Hendren ${ }^{10} 6$ Gy (Table II).

There has been no prospective, randomised trial of the possible methods of preventing HO. Kjaersgaard-Andersen and Ritter ${ }^{11}$ studied indomethacin and acetylsalicylic acid but did not report their study design. Sodemann, Persson and Nilsson ${ }^{12}$ compared indomethacin and ibuprofen prospectively, but the study was not randomised. Our aim was to compare acetylsalicylic acid, indomethacin for 7 and 14 days, one fractional irradiation and two different single doses of irradiation after operation in a prospective, randomised controlled study. 
Table I. Reported incidence of $\mathrm{HO}$ after administration of indomethacin. The number for the untreated control group, if given, is shown after the dash

\begin{tabular}{|c|c|c|c|c|c|}
\hline Authors & Year & $\begin{array}{l}\text { Dosage } \\
\text { (mg, duration) }\end{array}$ & $\begin{array}{l}\text { Number of } \\
\text { patients }\end{array}$ & $\begin{array}{l}\text { Incidence of } \\
\text { HO }(\%)\end{array}$ & $\begin{array}{l}\text { Significant } \\
\text { HO }(\%)^{*}\end{array}$ \\
\hline $\mathrm{Dahl}^{7}$ & 1975 & $3 \times 50,1 \mathrm{wks}$ & 39 & - & $16(\mathrm{e})$ \\
\hline Almåsbakk and Røysland ${ }^{34}$ & 1977 & $3 \times 25,4$ wks & $27 / 54$ & $37 / 74$ & - \\
\hline Ritter and Gioe ${ }^{35}$ & 1982 & $3 \times 25,6 \mathrm{wks}$ & $24 / 24$ & $17 / 64$ & $0 / 29(\mathrm{~h})$ \\
\hline Ritter and Siebert ${ }^{36}$ & 1985 & $3 \times 25,6 \mathrm{wks}$ & $528 / 525$ & $10 / 26$ & $2 / 6(\mathrm{~h})$ \\
\hline Kjaersgaard-Andersen and Schmidt $\dagger^{37}$ & 1986 & $3 \times 25,6 \mathrm{wks}$ & $12 / 0$ & $50 /-$ & $25 /-(\mathrm{e})$ \\
\hline Steenmeyer, Slooff and Kuypers $\dagger^{38}$ & 1986 & $2 \times 25,6 \mathrm{wks}$ & $25 / 0$ & $32 /-$ & $0 /-(b)$ \\
\hline Cella, Salvati and Sculco ${ }^{36}$ & 1988 & $3 \times 25,6 \mathrm{wks}$ & $47 / 64$ & $60 / 67$ & $0 / 10(\mathrm{~b})$ \\
\hline Knahr et $\mathrm{al}^{15}$ & 1988 & $2 \times 50,2 \mathrm{wks}$ & 36 & 17 & 0 (a) \\
\hline Schmidt et al $\dagger^{40}$ & 1988 & $3 \times 25,6 \mathrm{wks}$ & $102 / 99$ & $13 / 73$ & $0 / 48(\mathrm{~d})$ \\
\hline Sodemann et al $\dagger^{12}$ & 1988 & $2 \times 50,21$ days & $136 / 34$ & $5 / 52$ & $0 / 23$ (b) \\
\hline Hochheim and Wünsche ${ }^{41}$ & 1990 & $3 \times 25, ?$ & $63 / 100$ & $75 / 54$ & $5 / 24(\mathrm{e})$ \\
\hline McLaren $\dagger^{42}$ & 1990 & $3 \times 25,6 \mathrm{wks}$ & $18 / 26$ & $50 / 65$ & $0 / 38$ (b) \\
\hline McMahon et $\mathrm{al}^{16}$ & 1991 & $3 \times 25,10$ days & $85 / 100$ & $20 / 70$ & $1 / 24$ (b) \\
\hline Metzenroth et $\mathrm{al}^{43}$ & 1991 & $3 \times 25,20$ days & 96 & 14 & 0 \\
\hline Kjaersgaard-Andersen and Ritter ${ }^{11}$ & 1992 & $3 \times 25,14$ days & $15 / 0$ & $0 /-$ & $0 /-(d)$ \\
\hline Randelli and Romanò $\dagger^{17}$ & 1992 & $2 \times 50,14$ days & $40 / 60$ & $7 / 30$ & $0 / 5$ (b) \\
\hline Tözün et $\mathrm{al}^{44}$ & 1992 & $3 \times 25,4$ wks & $29 / 27$ & $31 / 43$ & $0 / 30$ (b) \\
\hline Wurnig, Eyb and Auersperg ${ }^{45}$ & 1992 & $2 \times 50,6 \mathrm{wks}$ & $100 / 100$ & $41 / 81$ & $6 / 28$ (b) \\
\hline Goutallier et al $\dagger^{18}$ & 1993 & $3 \times 25,8$ days & $21 / 60$ & $9 / 27$ & $0 / 10$ (b) \\
\hline
\end{tabular}

* the significance of HO is defined as higher grades of HO in the different grading systems: (b) = Brooker 3 to 4 ; (d) $=$ DeLee 2 to 3 (=Arq); (e) = own classification; (h) = Hamblen 2 to 3

$\dagger$ including patients with risk factors

Table II. Reported incidence of HO after prophylactic irradiation. The number for the untreated control group, if given, is shown after the dash

\begin{tabular}{|c|c|c|c|c|c|}
\hline Authors & Year & $\begin{array}{l}\text { Dose } \\
\text { (Gy, fractions) }\end{array}$ & $\begin{array}{l}\text { Number of } \\
\text { patients }\end{array}$ & $\begin{array}{l}\text { Incidence } \\
\text { of HO }(\%)\end{array}$ & $\begin{array}{l}\text { Significant } \\
\text { HO }(\%)^{*}\end{array}$ \\
\hline Coventry and Scanlon ${ }^{8}$ & 1981 & $20(10 \times 2)$ & 48 & 50 & 0 \\
\hline Parkinson et $\mathrm{al}^{14}$ & 1982 & $20(10 \times 2)$ & 64 & 8 & 3 \\
\hline MacLennan et $\mathrm{al}^{46}$ & 1985 & $20(10 \times 2)$ & 67 & 16 & 5 \\
\hline Van der Werf, van Hasselt and Tonino ${ }^{47}$ & 1985 & $20(10 \times 2)$ & 16 & 81 & 0 \\
\hline Evarts, Ayers and Puzas ${ }^{48}$ & 1986 & $10(5 \times 2)$ & $47 / 54$ & $28 / 69$ & $0 /-$ \\
\hline \multirow[t]{2}{*}{ Anthony et $\mathrm{al}^{19}$} & 1987 & $20(10 \times 2)$ & 62 & 3 & 0 \\
\hline & & $10(5 \times 2)$ & 41 & 5 & 5 \\
\hline \multirow[t]{2}{*}{ Brunner, Morscher and Hünig ${ }^{49}$} & 1987 & $20(10 \times 2)$ & 16 & 19 & 6 \\
\hline & & $20(10 \times 2) \dagger$ & 10 & 70 & 33 \\
\hline Jasty et $\mathrm{l}^{20}$ & 1988 & $15(5 \times 3)$ & 18 & 11 & 0 \\
\hline Lo et $\mathrm{al}^{9}$ & 1988 & $7(1 \times 7)$ & 24 & 16 & 0 \\
\hline Reining et $\mathrm{al}^{50}$ & 1988 & $20(10 \times 2)$ & 13 & 0 & 0 \\
\hline Hedley et $\mathrm{al}^{10}$ & 1989 & $6(1 \times 6)$ & 16 & 27 & 0 \\
\hline \multirow[t]{2}{*}{ Conterato et $\mathrm{al}^{51}$} & 1989 & $5(2 \times 2.5)$ & 30 & 20 & 3 \\
\hline & & $10(2 \times 5)$ & 15 & 20 & 0 \\
\hline Kennedy et $\mathrm{al}^{52}$ & 1989 & $10(5 \times 2)$ & $42 / 86$ & $38 / 66$ & $7 / 32$ \\
\hline Healy et $\mathrm{al}^{23}$ & 1990 & $7(1 \times 7)$ & 34 & 8 & 4 \\
\hline Karstens et $\mathrm{al}^{53}$ & 1990 & $8(5 \times 1.6)$ & 29 & 7 & 0 \\
\hline \multirow[t]{2}{*}{ Konski et $\mathrm{al}^{21}$} & 1990 & $10(5 \times 2)$ & 20 & 10 & 0 \\
\hline & & $8(1 \times 8)$ & 17 & 6 & 0 \\
\hline Maloney et $\mathrm{al}^{54}$ & 1990 & $7.5(3 \times 2.5)$ & 14 & 20 & 0 \\
\hline Gehl et $\mathrm{al}^{22}$ & 1991 & $10(5 \times 2)$ & 26 & 8 & 0 \\
\hline \multirow[t]{2}{*}{ Pellegrini et $\mathrm{al}^{55}$} & 1992 & $10(5 \times 2)$ & 28 & 32 & 7 \\
\hline & & $8(1 \times 8)$ & 34 & 35 & 6 \\
\hline \multirow[t]{2}{*}{ Warren $^{24}$} & 1992 & $10(5 \times 2)$ & 10 & 17 & 0 \\
\hline & & $7(1 \times 7)$ & 3 & & \\
\hline De Flitch and Stryker ${ }^{56}$ & 1993 & $7(1 \times 7)$ & 33 & 63 & 9 \\
\hline \multirow[t]{3}{*}{ Goldmann et $\mathrm{al}^{57^{\circ}}$} & 1993 & $10(5 \times 2)$ & 32 & 9 & 0 \\
\hline & & $17.5(5 \times 3.5)$ & 20 & 0 & 0 \\
\hline & & $20(10 \times 2)$ & 8 & 12 & 12 \\
\hline \multirow[t]{2}{*}{${\text { Gregoritch et } \mathrm{al}^{58}}^{58}$} & 1993 & $1 \times 7$ to 8 postop & 39 & 21 & 0 \\
\hline & & $1 \times 7$ to 8 preop & 47 & 25 & 4 \\
\hline \multirow[t]{2}{*}{ Seegenschmiedt et al $^{59}$} & 1993 & $10(5 \times 2)$ & 73 & 5 & 2 \\
\hline & & $17.5(5 \times 3.5)$ & 68 & 12 & 0 \\
\hline \multirow[t]{2}{*}{ Seegenschmiedt et al ${ }^{60}$} & 1994 & $17.5(5 \times 3.5)$ & 21 & 52 & 9 \\
\hline & & $1 \times 7$ preop & 23 & 52 & 4 \\
\hline
\end{tabular}

* significance of HO is defined as grades 3 to 4 according to Brooker

$\dagger$ in this group therapy began after the 7 th day 
Table III. The incidence of HO after total hip arthroplasty

\begin{tabular}{|c|c|c|c|c|c|}
\hline Authors & Year & $\begin{array}{l}\text { Follow-up } \\
\text { (mth) }\end{array}$ & $\begin{array}{l}\text { Number of } \\
\text { patients }\end{array}$ & $\begin{array}{l}\text { Incidence } \\
\text { of } \mathrm{HO}(\%)\end{array}$ & $\begin{array}{l}\text { Significant } \\
\text { HO }(\%)^{*}\end{array}$ \\
\hline Hamblen, Harris amd Rottger ${ }^{61}$ & 1971 & - & 422 & 20 & $3(\mathrm{~h})$ \\
\hline Charnley $^{62}$ & 1972 & 48 & 379 & - & $5(\mathrm{e})$ \\
\hline Brooker et $\mathrm{al}^{13}$ & 1973 & 6 & 100 & 21 & 9 (b) \\
\hline Nollen and van Douveren ${ }^{63}$ & 1973 & 12 & 546 & 57 & $21(\mathrm{e})$ \\
\hline Lazansky $^{26}$ & 1973 & 6 & 501 & 8 & $3(\mathrm{e})$ \\
\hline Hanslik and Radloff $^{64}$ & 1974 & 12 & 356 & 36 & $7(\mathrm{e})$ \\
\hline Matos, Amstutz and Finerman ${ }^{65}$ & 1975 & - & 221 & 41 & $13(\mathrm{e})$ \\
\hline Caron 66 & 1976 & - & 2424 & 35 & $7(\mathrm{e})$ \\
\hline Riegler and Harris ${ }^{67}$ & 1976 & 4 & 102 & 51 & $9(\mathrm{e})$ \\
\hline Taylor, Kamdar and Arden ${ }^{68}$ & 1976 & - & 370 & - & $13(\mathrm{e})$ \\
\hline Almåsbakk and Røysland ${ }^{34}$ & 1977 & 3 & 54 & 74 & \\
\hline Holz, Kraner and Weller ${ }^{69}$ & 1977 & 3 & 676 & 46 & $9(\mathrm{e})$ \\
\hline Jowsey et $\mathrm{al}^{1}$ & 1977 & 12 & 224 & - & $12(\mathrm{e})$ \\
\hline Ritter and Vaughan ${ }^{70}$ & 1977 & 24 & 507 & 30 & $7(\mathrm{~h})$ \\
\hline Rosendahl et $\mathrm{al}^{27}$ & 1977 & 24 & 70 & 90 & $24(\mathrm{e})$ \\
\hline Mollan 71 & 1979 & 24 & 131 & 18 & $-(?)$ \\
\hline Kromann-Andersen et $\mathrm{al}^{72}$ & 1980 & 3 & 183 & 49 & $17(\mathrm{~d})$ \\
\hline Blasingame et $\mathrm{al}^{73}$ & 1981 & 12 & 69 & 81 & 17 (b) \\
\hline Hierton, Blomgren and Lindgren ${ }^{74}$ & 1983 & 36 & 237 & 24 & \\
\hline Ritter and Gioe ${ }^{35}$ & 1992 & 6 & 24 & 64 & $29(\mathrm{~h})$ \\
\hline Errico, Fetto and Waugh ${ }^{75}$ & 1984 & 6 & 100 & 58 & $17(\mathrm{~d})$ \\
\hline Morrey, Adams and Cabanela ${ }^{76}$ & 1984 & - & 507 & 78 & 27 (d) \\
\hline Elmstedt et $\mathrm{al}^{77}$ & 1985 & 12 & 22 & 75 & $55(\mathrm{e})$ \\
\hline Ritter and Sieber ${ }^{36}$ & 1985 & 60 & 525 & 26 & $6(\mathrm{~h})$ \\
\hline Thomas and Amstutz ${ }^{78}$ & 1985 & 36 & 200 & 66 & $18(\mathrm{~b})$ \\
\hline Lindholm et $\mathrm{al}^{79}$ & 1986 & 6 & 623 & 53 & $5(\mathrm{e})$ \\
\hline Sundaram and Murphy ${ }^{80}$ & 1986 & 12 & 98 & 40 & $11(\mathrm{~d})$ \\
\hline Cella et $\mathrm{al}^{39}$ & 1988 & 6 & 64 & 67 & $10(\mathrm{~b})$ \\
\hline Schmidt et $\mathrm{al}^{40}$ & 1988 & 12 & 99 & 73 & $48(\mathrm{~d})$ \\
\hline Søballe, Christensen and Kristensen ${ }^{81}$ & 1988 & 12 & 129 & 63 & $12(\mathrm{e})$ \\
\hline Sodemann et $\mathrm{al}^{30}$ & 1988 & 12 & 150 & 67 & 23 (b) \\
\hline Testa and Mazur ${ }^{82}$ & 1988 & 6 & 90 & 60 & 11 (b) \\
\hline Ahrengart and Lindgren ${ }^{83}$ & 1989 & 12 & 145 & 75 & 21 (b) \\
\hline Müller and Koch ${ }^{84}$ & 1989 & - & 6026 & 38 & 8 (b) \\
\hline Hochheim and Wünsche ${ }^{41}$ & 1990 & 18 & 100 & 54 & $24(\mathrm{e})$ \\
\hline Hoikka, Lindholm and Eskola ${ }^{85}$ & 1990 & 6 & 32 & 45 & $19(\mathrm{e})$ \\
\hline Kjaersgaard-Andersen et $\mathrm{al}^{86}$ & 1990 & - & 40 & 65 & 32 (b) \\
\hline McLaren ${ }^{42}$ & 1990 & 12 & 26 & 65 & 38 (b) \\
\hline Gebuhr et $\mathrm{al}^{87}$ & 1991 & 12 & 27 & 56 & 30 (b) \\
\hline McMahon et $\mathrm{al}^{16}$ & 1991 & 24 & 100 & 70 & 24 (b) \\
\hline Wahlström et $\mathrm{al}^{88}$ & 1991 & 12 & 47 & 70 & \\
\hline Randelli and Romanò $^{17}$ & 1992 & 12 & 60 & 30 & 5 (b) \\
\hline Reis, Küsswetter and Schellinger ${ }^{89}$ & 1992 & 12 & 65 & 55 & 17 (a) \\
\hline Tözün et $\mathrm{al}^{44}$ & 1992 & 6 & 27 & 43 & 30 (b) \\
\hline Wurnig et $\mathrm{al}^{45}$ & 1992 & 12 & 100 & 81 & $28(\mathrm{~d})$ \\
\hline Nollen and van Douveren ${ }^{90}$ & 1993 & 12 & 637 & 57 & 21 (b) \\
\hline
\end{tabular}

* significant ossification is defined as that consistent with the highest degree of the grading system used (see Table I)

Table IV. Reasons for withdrawing from prophylactic therapy

\begin{tabular}{lc}
\hline & Number \\
\hline Gastric disorder & 13 \\
Fever & 1 \\
Allergy & 1 \\
Death & 1 \\
Delay in initiating prophylaxis & 3 \\
Radiation machine defect & 2 \\
Unavailable for postoperative examination & 23 \\
Other & 4 \\
\hline
\end{tabular}

\section{PATIENTS AND METHODS}

From 1988 to 1994 we performed 733 total hip replacements in 723 patients at the University Hospital, Würzburg. The patients in the control group were operated on between
1988 and 1992 and those in the treatment groups from the end of 1992 to the end of 1994. They were assigned to one of the six regimes using a random-number table as follows (see Table VIII):

Group 1: 93 patients received $3 \times 750 \mathrm{mg}$ of acetylsalicylic acid (Godamed; Chemische Fabrik GmbH, Bamberg, Germany) per day with mucoprotection for 14 days, beginning on the first postoperative day.

Group 2: 90 patients had $2 \times 50 \mathrm{mg}$ of indomethacin (Indomet 50; Ratiopharm GmbH \& Co, Ulm, Germany) per day with mucoprotection for 14 days beginning on the first postoperative day.

Group 3: 113 patients received $2 \times 50 \mathrm{mg}$ of indomethacin (Durametacin) per day with mucoprotection with $2 \times 50 \mathrm{mg}$ of pirencepin (Pirexexal, Hexal AG, Holzkirchen, Germany) for seven days beginning on the first postoperative day. 
Table V. The appearance of side-effects related to the type of prophylactic therapy. The number of withdrawals is in bold type

\begin{tabular}{|c|c|c|c|c|c|c|c|}
\hline Side-effects & $\begin{array}{l}\text { ASA* } \\
14 \text { days }\end{array}$ & $\begin{array}{l}\text { Indomethacin } \\
14 \text { days }\end{array}$ & $\begin{array}{l}\text { Indomethacin } \\
7 \text { days }\end{array}$ & $\begin{array}{l}\text { Irradiation } \\
\mathbf{4} \times 3 \mathbf{G y}\end{array}$ & $\begin{array}{l}\text { Irradiation } \\
1 \times 7 \text { Gy }\end{array}$ & $\begin{array}{l}\text { Irradiation } \\
1 \times 5 \text { Gy }\end{array}$ & Control group \\
\hline Number of hips & 99 & 94 & 118 & 102 & 95 & 93 & 100 \\
\hline $\begin{array}{l}\text { Number of hips } \\
\text { without withdrawals }\end{array}$ & 93 & 90 & 113 & 101 & 95 & 93 & 100 \\
\hline Gastric disorder & $6 / 4$ & $4 / 1$ & 0 & 0 & 0 & 0 & 0 \\
\hline Nausea/vomiting & 2 & $7 / 3$ & $14 / 5$ & 0 & 3 & 6 & 0 \\
\hline Headache & 0 & 1 & 0 & 1 & 0 & 0 & 0 \\
\hline Fever & 0 & 1 & 10 & $19 / 1$ & 25 & 26 & 0 \\
\hline Allergic reaction & $1 / 1$ & 0 & 6 & 0 & 0 & 0 & 0 \\
\hline Others & $2 / 1$ & 3 & 9 & 2 & 3 & 4 & 0 \\
\hline Total (number, \%) & $11 / 6(11.1 / 6.1)$ & $16 / 4(17 / 4.3)$ & $39 / 5(33.1 / 4.2)$ & $22 / 1(21.6 / 1)$ & $31(32.6)$ & $36(38.7)$ & $0(0)$ \\
\hline
\end{tabular}

* acetylsalicylic acid

Table VI. The incidence of HO in 685 hips by percentage

\begin{tabular}{|c|c|c|c|c|c|c|c|}
\hline \multirow[b]{2}{*}{ Treatment } & \multirow{2}{*}{$\begin{array}{l}\text { Number } \\
\text { of hips }\end{array}$} & \multicolumn{6}{|c|}{ Brooker $^{13}$ grading system } \\
\hline & & $\mathbf{0}$ & 1 & 2 & 3 & 4 & 1 to 4 \\
\hline Acetylsalicylic acid & 93 & 62.4 & 28 & 4.3 & 5.3 & 0 & 37.6 \\
\hline Indomethacin 14 days & 90 & 87.8 & 8.9 & 2.2 & 1.1 & 0 & 12.2 \\
\hline Indomethacin 7 days & 113 & 84.1 & 8.0 & 6.2 & 1.7 & 0 & 15.9 \\
\hline Irradiation 4 × 3 Gy & 101 & 95.0 & 5.0 & 0 & 0 & 0 & 5.0 \\
\hline Irradiation $1 \times 7$ Gy & 95 & 88.4 & 11.6 & 0 & 0 & 0 & 11.6 \\
\hline Irradiation 1 x 5 Gy & 93 & 69.9 & 24.7 & 4.3 & 1.1 & 0 & 30.1 \\
\hline Total & 585 Mean & 81.6 & 14 & 2.9 & 1.5 & 0 & 18.4 \\
\hline Control group & 100 & 35.0 & 26.0 & 15.0 & 19.0 & 5.0 & 65.0 \\
\hline
\end{tabular}

Table VII. Significance among all treatment groups concerning the total percentage of HO (chi-squared test used; significance is defined as $\mathrm{p} \leq 0.05$, in bold type; trends are in italics)

\begin{tabular}{|c|c|c|c|c|c|c|}
\hline & $\begin{array}{l}\text { ASA* } \\
14 \text { days } \\
(n=35) \\
37.6 \%\end{array}$ & $\begin{array}{l}\text { Indomethacin } \\
7 \text { days } \\
(n=18) \\
16 \%\end{array}$ & $\begin{array}{l}\text { Indomethacin } \\
14 \text { days } \\
(\mathrm{n}=11) \\
12.2 \%\end{array}$ & $\begin{array}{l}\text { Irradiation } \\
4 \times 3 \text { Gy } \\
(n=5) \\
5 \%\end{array}$ & $\begin{array}{l}\text { Irradiation } \\
1 \times 7 \text { Gy } \\
(\mathbf{n}=11) \\
11.6 \%\end{array}$ & $\begin{array}{l}\text { Irradiation } \\
1 \times 5 \text { Gy } \\
(\mathbf{n}=\mathbf{2 8}) \\
\mathbf{3 0 . 1} \%\end{array}$ \\
\hline Control group $(n=65) 65 \%$ & 0.001 & 0.001 & 0.001 & 0.001 & 0.001 & 0.001 \\
\hline ASA 14 days $(n=35) 37.6 \%$ & & 0.001 & 0.001 & 0.001 & 0.001 & 0.28 \\
\hline Indomethacin 7 days $(n=18) 16 \%$ & & & 0.45 & $<0.001$ & 0.36 & 0.015 \\
\hline Indomethacin 14 days $(n=11) 12.2 \%$ & & & & 0.068 & 0.89 & 0.003 \\
\hline Irradiation $4 \times 3$ Gy $(n=5) 5 \%$ & & & & & 0.087 & 0.001 \\
\hline Irradiation $1 \times 7$ Gy $(n=11) 11.6 \%$ & & & & & & $<0.015$ \\
\hline
\end{tabular}

Group 4: 101 patients received four doses of irradiation of 3 Gy at two-day intervals beginning no later than the fifth postoperative day.

Group 5: 95 patients had one dose of irradiation of 7 Gy no later than the fifth postoperative day.

Group 6: 93 patients had one dose of irradiation of 5 Gy no later than the fifth postoperative day.

Group 7: 100 patients from the years 1988 to 1992 were untreated and were used as the control group.

Postoperative pain was treated only with tramadol (Tramal; Grünenthal GmbH, Aachen, Germany), paracetamol (Ben-uron; Bene-Arznei mittel $\mathrm{GmbH}$, München, Germany) or piritamid (Dipidolor; Janssen GmbH, Neuss, Germany). No additional NSAIDs were used as postoperative analgesia.

All groups were investigated for diagnosis, age, gender, side of operation, time of follow-up, previous operations and postoperative ossification. No differences were found except for the diagnosis which was ignored since it does not influence the risk of development of HO.
The control group were from an earlier period and had not received NSAIDs before or after operation. A treatment-free acute control group was not acceptable to us for ethical reasons, since a high incidence of $\mathrm{HO}$ would be expected (Tables I to III).

Anteroposterior and Lauenstein radiographs were taken immediately after operation and again after 3 and 12 months. We used the HO classification of Brooker et $\mathrm{al}^{13}$ extended according to Parkinson et al. ${ }^{14}$

We reviewed 677 patients (685 hips) at 3 and 12 months after operation; 15 had to stop prophylactic therapy because of side-effects (Tables IV and V) and 31 could not be reviewed for reasons which were not related to their treatment (Table IV).

\section{RESULTS}

The amount of HO depended on the type of prophylaxis, but overall $18.4 \%$ of the hips developed HO; $14.0 \%$ were 
Table VIII. Distribution of patients in the different treatment groups

\begin{tabular}{|c|c|c|c|c|c|c|c|c|}
\hline & \multicolumn{3}{|c|}{ Irradiation } & \multicolumn{2}{|c|}{ Indomethacin } & $\frac{\mathrm{ASA}^{*}}{14 \text { days }}$ & $\begin{array}{l}\text { Control } \\
\text { group }\end{array}$ & Total \\
\hline Number of hips & 93 & 95 & 101 & 113 & 90 & 93 & 100 & 685 \\
\hline Female & 64 & 54 & 56 & 72 & 61 & 64 & 69 & 409 \\
\hline Mean age (yr) & 66.2 & 67.3 & 66.9 & 64.7 & 67 & 66.5 & 65.3 & 66.3 \\
\hline $\begin{array}{l}\text { Fixation of stem } \\
\text { Cemented } \\
\text { Uncemented }\end{array}$ & $\begin{array}{l}63 \\
30\end{array}$ & $\begin{array}{l}63 \\
26\end{array}$ & $\begin{array}{l}76 \\
23\end{array}$ & $\begin{array}{l}71 \\
36\end{array}$ & $\begin{array}{l}69 \\
18\end{array}$ & $\begin{array}{l}66 \\
23\end{array}$ & $\begin{array}{l}64 \\
36\end{array}$ & $\begin{array}{l}470 \\
191\end{array}$ \\
\hline $\begin{array}{l}\text { Diagnosis } \\
\text { Arthritis } \\
\text { AVN } \\
\text { Hip revision surgery } \\
\text { Femoral neck fracture } \\
\text { Girdlestone }\end{array}$ & $\begin{array}{r}85 \\
3 \\
2 \\
0 \\
3\end{array}$ & $\begin{array}{r}65 \\
7 \\
19 \\
3 \\
1\end{array}$ & $\begin{array}{r}83 \\
9 \\
7 \\
1 \\
1\end{array}$ & $\begin{array}{r}77 \\
11 \\
20 \\
5 \\
0\end{array}$ & $\begin{array}{r}70 \\
4 \\
12 \\
2 \\
2\end{array}$ & $\begin{array}{r}65 \\
13 \\
10 \\
3 \\
2\end{array}$ & $\begin{array}{r}74 \\
9 \\
6 \\
11 \\
0\end{array}$ & $\begin{array}{r}519 \\
56 \\
76 \\
25 \\
9\end{array}$ \\
\hline $\begin{array}{l}\text { Preoperations } \\
\text { Same side } \\
\text { Other side }\end{array}$ & $\begin{array}{r}6 \\
18\end{array}$ & $\begin{array}{l}19 \\
27\end{array}$ & $\begin{array}{r}7 \\
19\end{array}$ & $\begin{array}{l}19 \\
27\end{array}$ & $\begin{array}{l}12 \\
18\end{array}$ & $\begin{array}{l}10 \\
20\end{array}$ & $\begin{array}{r}6 \\
20\end{array}$ & $\begin{array}{r}73 \\
129\end{array}$ \\
\hline
\end{tabular}

grade I, $2.9 \%$ grade II and $1.5 \%$ grade III (Table VI). There were no cases of ankylosis (grade IV) (Table VI). Table VI shows the distribution of $\mathrm{HO}$ among each group. The groups were compared using the chi-squared test. This showed that each of the treatment regimes differed significantly from the control group $(\mathrm{p}=0.001)$ (Table VII). Side-effects (Table V). Side-effects were found in 155 patients $(22 \%)$, and in $15(2.2 \%)$ were sufficient to warrant withdrawal of the patient from the trial.

In the drug groups gastrointestinal problems were encountered in 33 patients; 13 of these had to stop treatment. There was one case of headache, 11 of pyrexia and seven of allergic reaction.

In the irradiation group nine patients complained of gastrointestinal symptoms and 70 had a fever. Fractional irradiation therapy had to be interrupted in one patient because of secondary pyrexia (Tables IV and V).

\section{DISCUSSION}

Our results using indomethacin are similar to those reported by other authors ${ }^{15-18}$ (Table I). The incidence of HO which we observed in our groups treated by irradiation is also similar to those previously published ${ }^{9,10,19-24}$ (Table II), although it must be emphasised that most of these series had been of high-risk patients.

Postoperative irradiation with $1 \times 5 \mathrm{~Gy}$ and prophylaxis with acetylsalicylic acid gave significantly worse results than the other methods (Tables VI and VII). We included acetylsalicylic acid because of the good results reported by Freiberg, Cantor and Freiberg ${ }^{25}$ in 1991 and KjaersgaardAndersen and Ritter in $1992,{ }^{11}$ but we were not able to confirm their observations.

The incidence of $\mathrm{HO}$ in the group treated by $4 \times 3 \mathrm{~Gy}$
(5\%) was significantly lower $(\mathrm{p}=0.068)$ than in the patients treated by indomethacin for 14 days $(12.2 \%)$; the latter group showed some Brooker grade-II changes whereas the former had only Brooker grade-I (Tables VI and VII).

The group which was treated by four exposures of $3 \mathrm{~Gy}$ after operation had an incidence of $5 \% \mathrm{HO}$ which was significantly better $(\mathrm{p}=0.087)$ than that of those treated by exposure to $7 \mathrm{~Gy}(11.6 \%)$. Both groups showed ossification to Brooker grade-I only, which is of no clinical significance; we therefore prefer the single dose.

Published studies describe an incidence of $\mathrm{HO}$ of between $8 \%$ and $90 \%$ in untreated patients ${ }^{26,27}$ (Table III). This can be partly explained by varying periods of followup and differences in the study design and classification systems. $^{28-30}$ Most of the reports do not state whether additional NSAIDs were used in the postoperative period, and very few statistically sound studies have been reported.

In our patients taking indomethacin or acetylsalicylic acid $22 \%$ had undesirable side-effects, mostly gastrointestinal and $2.2 \%$ had to be withdrawn from the study (Table V). In general, clinically relevant symptoms after the administration of NSAIDs occur in $25 \%$ to $30 \%$ of patients, and in those over 65 years the incidence is between $31 \%$ and $38 \% .^{31}$ Lesions of the mucosa may occur without symptoms. ${ }^{31-33}$ We excluded patients with previous symptoms suggestive of ulceration.

Conclusions. Indomethacin should be given as general prophylaxis against $\mathrm{HO}$ immediately after operation in a dose of $2 \times 50 \mathrm{mg}$ for seven days with a mucoprotective drug. In patients who have developed HO after a previous operation or in whom NSAIDs are contraindicated, a single dose of irradiation of 7 Gy should be used. 
No benefits in any form have been received or will be received from a commercial party related directly or indirectly to the subject of this article.

\section{REFERENCES}

1. Jowsey J, Coventry MB, Robins PR. Heterotopic ossification: theoretical consideration, possible etiologic factors, and a clinical review of hip arthroplasty patients exhibiting this phenomenon. In: The Hip. Proceedings of the Fifth Open Scientific Meeting of the Hip Society. St Louis: CV Mosby, 1977:210-21.

2. Rudicel S. Paraarticular (ectopic or heterotopic) ossification following total hip prosthesis. Orthopäde 1985;14:54-7.

3. Nollen AJG, Slooff TJJH. Para-articular ossification after total hip replacement. Acta Orthop Scand 1973;44:230-41.

4. Friedenstein AY. Induction of bone tissue by transitional epithelium. Clin Orthop 1968;59:21-37.

5. Owen M. The origin of bone cells in the postnatal organism. Arthr Rheum 1980;23:1073-80.

6. Owen M. Cell population kinetics of an osteogenic tissue I. J Cell Biol 1963;19:19-32.

7. Dahl HK. Klinske Observasjoner. In: Symposium on Arthrose, Ed MSD. Blindern, Norway, 1975:37-46.

8. Coventry MB, Scanlon PW. The use of radiation to discourage ectopic bone: a nine-year study in surgery about the hip. J Bone Joint Surg [Am] 1981;63-A:201-8.

9. Lo TCM, Healy WL, Covall DJ, et al. Heterotopic bone formation after hip surgery: prevention with single-dose postoperative hip irradiation. Radiology 1988;168:851-4.

10. Hedley AK, Mead LP, Hendren DH. The prevention of heterotopic bone formation following total hip arthroplasty using $600 \mathrm{rad}$ in a single dose. J Arthroplasty 1989;4:319-25.

11. Kjaersgaard-Andersen $\mathbf{P}$, Ritter $\mathbf{M}$. Short-term treatment with nonsteroidal antiinflammatory medications to prevent heterotopic bone formation after total hip arthroplasty: a preliminary report. Clin Orthop 1992;279:157-62.

12. Sodemann B, Persson P-E, Nilsson OS. Prevention of heterotopic ossification by nonsteroid antiinflammatory drugs after total hip arthroplasty. Clin Orthop 1988;237:158-63.

13. Brooker AF, Bowerman JW, Robinson RA, Riley LH Jr. Ectopic ossification following total hip replacement: incidence and method of classification. J Bone Joint Surg [Am] 1973;55-A:1629-32.

14. Parkinson JR, Evarts CM, Hubbard LF. Radiation therapy in the prevention of heterotopic ossification after total hip arthroplasty. In: Murray WR, ed. The Hip. Proceedings of the 10th Open Scientific Meeting of the Hip Society. St Louis, CV Mosby, 1982:211-27.

15. Knahr K, Salzer M, Eyb R, Frank P, Blauensteiner W. Heterotopic ossification with total hip endoprostheses in various models of thrombosis prophylaxis. $J$ Arthroplasty 1988;3:1-8.

16. McMahon JS, Waddell JP, Morton J. Effect of short-course indomethacin on heterotopic bone formation after uncemented total hip arthroplasty. J Arthroplasty 1991;6:259-64.

17. Randelli G, Romanò CL. Prophylaxis with indomethacin for heterotopic ossification after Chiari osteotomy of the pelvis. J Bone Joint Surg [Am] 1992;74-A:1344-6.

18. Goutallier D, Colmar M, Penot P. Heterotopic ossification of the hip: the influence of the duration of postoperative treatment with indomethacin on the prevention of ossification and the effect of uncemented acetabular implants on the development of ossification. J Orthop Surg 1993;7:144-50.

19. Anthony P, Keys H, Evarts CM, Rubin P, Lush C. Prevention of heterotopic bone formation with early postoperative irradiation in high risk patients undergoing total hip arthroplasty: comparison of $10 \mathrm{~Gy}$ vs 20 Gy schedules. Int J Radiat Oncol Biol Phys 1987;13:365-9.

20. Jasty M, Schutzer S, Tepper J, et al. Radiation-blocking shields to localise periarticular radiation precisely for prevention of heterotopic bone formation around uncemented total hip arthroplasties. Clin Orthop 1990;257:138-45.

21. Konski A, Weiss C, Rosier R, et al. The use of postoperative irradiation for the prevention of heterotopic bone after total hip replacement with biologic fixation (porous-coated) prosthesis: an animal model. Int J Radiat Oncol Biol Phys 1990;18:861-5.

22. Gehl HB, Karstens JH, Casser HR, Savvidis E, Ammon J. The prevention of ectopic ossification in total hip endoprostheses: studies on field volume, total dosage and timing of postoperative radiotherapy. Röntgenpraxis 1991;44:117-20.
23. Healy WL, Lo TCM, Covall DJ, Pfeifer BA, Wasilewski SA. Single-dose radiation therapy for prevention of heterotopic ossification after total hip arthroplasty. J Arthroplasty 1990;5:369-75.

24. Warren SB. Heterotopic ossification after total hip replacement. Orthop Rev 1990;19:603-11.

25. Freiberg AA, Cantor R, Freiberg RA. The use of aspirin to prevent heterotopic ossification after total hip arthroplasty: a preliminary report. Clin Orthop 1991;267:93-6.

26. Lazansky MG. Complications revisited: the debit side of total hip replacement. Clin Orthop 1973;95:96-103.

27. Rosendahl S, Krogh Christoffersen J, Norgaard M. Para-articular ossification following hip replacement. Acta Orthop Scand 1977; 48:400-4.

28. Ahrengart L. Periarticular heterotopic ossification after total hip arthroplasty: risk factors and consequences. Clin Orthop 1991;263: 49-58.

29. Arcq M. Die paraartikulären Ossifikationen - eine Komplikation der Totalendoprothese des Hüftgelenkes. Arch Orthop Unfallchir 1973; 77:108-31.

30. Sodemann B, Persson P-E, Nilsson OS. Periarticular heterotopic ossification after total hip arthroplasty for primary coxarthrosis. Clin Orthop 1988;237:150-7.

31. Caruso I, Bianchi-Porro G. Gastroscopic evaluation of antiinflammatory agents. Br Med J 1980;280:75-8.

32. Collier DSJ, Pain JA. Ulcer perforation in the elderly and NSAIDs. Lancet 1986:971.

33. Somerville K, Faulkner G, Langman M. Non-steroidal anti-inflammatory drugs and bleeding peptic ulcer. Lancet 1986;1:462-4.

34. Almåsbakk K, Røysland P. Does indomethacin (IMC) prevent postoperative ectopic ossification in total hip replacement. Acta Orthop Scand 1977; 48:556.

35. Ritter MA, Gioe TJ. The effect of indomethacin on para-articular ectopic ossification following total hip arthroplasty. Clin Orthop 1982;167:113-7.

36. Ritter MA, Sieber JM. Prophylactic indomethacin for the prevention of heterotopic bone formation following total hip arthroplasty. Clin Orthop 1985;196:217-25.

37. Kjaersgaard-Andersen P, Schmidt SA. Indomethacin for prevention of ectopic ossification after hip arthroplasty. Acta Orthop Scand 1986;57:12-4

38. Steenmeyer AV, Slooff TJ, Kuypers W. The effect of indomethacin on para-articular ossification following total hip replacement. Acta Orthop Belg 1986;52:305-7.

39. Cella JP, Salvati EA, Sculco TP. Indomethacin for prevention of heterotopic ossification following total hip arthroplasty. J Arthroplasty $1988 \cdot 3 \cdot 229-34$.

40. Schmidt SA, Kjaersgaard-Andersen P, Pedersen NW, et al. The use of indomethacin to prevent the formation of heterotopic bone after total hip replacement: a randomized double-blind clinical trial. $J$ Bone Joint Surg [Am] 1988;70-A:834-8.

41. Hochheim B, Wünsche F. Indomethacin zur Prophylaxe Paraartikulärer Ossifikationen nach Hüft-Totalendoprothesen. Beitr Orthop Traumatol 1990;37:330-4.

42. McLaren AC. Prophylaxis with indomethacin for heterotopic bone after open reduction of fractures of the acetabulum. J Bone Joint Surg [Am] 1990;72-A:245-7.

43. Metzenroth H, Publig W, Knahr K, et al. Prevention of ossification after total hip endoprosthesis with indomethacin and its effect on gastric mucosa. Z Orthop Hire Grenzgeb 1991;129:178-82.

44. Tözün R, Pinar H, Yesiller E, Hamzaoglu A. Indomethacin for prevention of heterotopic ossification after total hip arthroplasty. J Arthroplasty 1992;7:57-61.

45. Wurnig C, Eyb R, Auersperg V. Indomethacin for prevention of ectopic ossification in cementless hip arthroplasties: a prospective 1-year study of 100 cases. Acta Orthop Scand 1992;63:628-30.

46. MacLennan I, Keys HM, Evarts CM, Rubin P. Usefulness of postoperative hip irradiation in the prevention of heterotopic bone formation in a high-risk group of patients. Int $J$ Radiat Oncol Biol Phys 1984;10:49-53.

47. Van der Werf GJ, van Hasselt NG, Tonino AJ. Radiotherapy in the prevention of recurrence of paraarticular ossification in total hip postheses. Arch Orthop Trauma Surg 1985;104:85-8. 
48. Evarts CM, Ayers DC, Puzas JE. Prevention of heterotopic bone formation in high-risk patients by postoperative irradiation. In: Brand R. The Hip. Proceedings of the 14th Open Scientific Meeting of the Hip Society. St Louis, CV Mosby, 1986:70-83.

49. Brunner R, Morscher E, Hünig R. Para-articular ossification in total hip replacement: an indication for irradiation therapy. Arch Orthop Trauma Surg 1987;106:102-7.

50. Reining J, Schäfer T, Pfab R, Hess F. Postoperative Strahlenbehandlung nach Hüfttotalendoprothese zur Prophylaxe periartikulärer Verknöcherungen: ein Therapeutisches Konzept. Med Welt 1988;39: 1542-4.

51. Conterato DJ, Verner J, Hartsell WF, et al. Prevention of heterotopic bone formation: comparison of 5 Gy versus $10 \mathrm{~Gy}$. Int J Radiat Oncol Biol Phys 1989;17, Suppl 1:232.

52. Kennedy WF, Gruen TA, Chessin H, Gasparini G, Thomson W. Radiation therapy to prevent heterotopic ossification after cementless total hip arthroplasty. Clin Orthop 1991;262:185-91

53. Karstens JH, Gehl H-B, Savvidis E, Casser HR, Löer F. Strahlentherapie: eine wirksame Prophylaxe periartikulärer Verknöcherungen nach Implantation von Hüftendoprothesen. Med Welt 1990;41: 1101-3.

54. Maloney WJ, Krushell RJ, Jasty M, Harris WH. Incidence of heterotopic ossification after total hip replacement: effect of the type of fixation of the femoral component. J Bone Joint Surg [Am] 1991; 72-A:191-3

55. Pellegrini VD, Konski AA, Gastel JA, Rubin P, Evarts CM. Prevention of heterotopic ossification with irradiation after total hip arthroplasty. J Bone Joint Surg [Am] 1992;74-A:186-200.

56. DeFlitch CJ, Stryker JA. Postoperative hip irradiation in prevention of heterotopic ossification: causes of treatment failure. Radiology 1993; 188:265-70.

57. Goldmann AR, Seegenschmiedt $M$, Andreas $P$, et al. Radiation therapy in the prevention of periarticular heterotopic ossification following implantation of a total hip endoprosthesis. Z Orthop Ihre Grenzgeb 1993;131:151-5.

58. Gregoritch S, Chadha M, Pellegrini V, Rubin P, Kantorowitz D. Randomized trial comparing pre-operative versus post-operative irradiation for prevention of heterotopic ossification following prosthetic total hip replacement: preliminary results. Int J Radiat Oncol Biol Phys 1994;30:55-62.

59. Seegenschmiedt MH, Goldmann AR, Martus P, et al. Prophylactic radiation therapy for prevention of heterotopic ossification after hip arthroplasty. Radiology 1993;188:257-64.

60. Seegenschmiedt MH, Martus P, Goldmann AR, et al. Preoperative versus postoperative radiotherapy for prevention of heterotopic ossification. Int J Radiat Oncol Biol Phys 1994;30:63-73.

61. Hamblen DL, Harris WH, Rottger J. Myositis ossificans as a complication of hip arthroplasty. J Bone Joint Surg [Br] 1971; 53-B:764.

62. Charnley J. The long-term results of low-friction arthroplasty of the hip performed as a primary intervention. J Bone Joint Surg [Br] 1972; 54-B:61-76.

63. Nollen AJG, van Douveren FQMP. Ectopic ossification in hip arthroplasty. Acta Orthop Scand 1973;64:185-7.

64. Hanslik $\mathbf{L}$, Radloff $\mathbf{H}$. The pathological significance of paraarticular ossifications after THRs. Arch Orthop Unfall Chir 1974;80:153-64.

65. Matos M, Amstutz HC, Finerman G. Myositis ossificans following total hip replacement. J Bone Joint Surg [Am] 1975;57-A:137.

66. Caron JC. Para-articular ossifications in total hip replacement. In: Gschwend N, Debrunner HV, eds. Total hip prosthesis. Bern: Hans Huber, 1976:171-85.

67. Riegler HF, Harris CM. Heterotopic bone formation after total hip arthroplasty. Clin Orthop 1976;117:209-16.

68. Taylor AR, Kamdar BA, Arden GP. Ectopic ossification following total hip replacement. J Bone Joint Surg [Br] 1976;58-B:134.
69. Holz U, Kraner F, Weller S. Periarticular ossification following replacement of the hip joint. Z Orthop 1977;115:146-58.

70. Ritter MA, Vaughan RB. Ectopic ossification after total hip arthroplasty: predisposing factors, frequency, and effect on results. $J$ Bone Joint Surg [Am] 1977;59-A:345-51.

71. Mollan RAB. Serum alkaline phosphatase in heterotopic para-articular ossification in total hip replacement. J Bone Joint Surg [Br] 1979; 61-B:432-4.

72. Kromann-Andersen C, Sørensen TS, Hougaard K, Zdravkovic D, Frigaard E. Ectopic bone formation following Charnley hip arthroplasty. Acta Orthop Scand 1980;51:633-8.

73. Blasingame JP, Resnick D, Coutts RD, Danzig LA. Extensive spinal osteophytosis as a risk factor for heterotopic bone formation after total hip arthroplasty. Clin Orthop 1981;161:191-7.

74. Hierton $\mathbf{C}$, Blomgren $\mathbf{G}$, Lindgren $\mathbf{U}$. Factors associated with heterotopic bone formation in cemented total hip prostheses. Acta Orthop Scand 1983;54:698-702.

75. Errico TJ, Fetto JF, Waugh TR. Heterotopic ossification: incidence and relation to trochanteric osteotomy in 108 total hip arthroplasties. Clin Orthop 1984;190:138-41.

76. Morrey BF, Adams RA, Cabanela ME. Comparison of heterotopic bone after anterolateral, transtrochanteric, and posterior approaches for total hip arthroplasty. Clin Orthop 1984;188:160-7.

77. EImstedt E, Lindholm TS, Nilsson OS, Törnkvist H. Effect of Ibuprofen on heterotopic ossification after hip replacement. Acta Orthop Scand 1985;56:25-7.

78. Thomas BJ, Amstutz HC. Results of the administration of diphosphonate for the prevention of heterotopic ossification after total hip arthroplasty. J Bone Joint Surg [Am] 1985;67-A:400-3.

79. Lindholm TS, Viljakka T, Vankka E, Popov L, Lindholm TC. Development of heterotopic ossification around the hip. Arch Orthop Trauma Surg 1986;105:263-7.

80. Sundaram NA, Murphy JCM. Heterotopic bone formation following total hip arthroplasty in ankylosing spondylitis. Clin Orthop 1986;207: 223-6.

81. Søballe K, Christensen F, Kristensen SS. Ectopic bone formation after total hip arthroplasty. Clin Orthop 1988;228:57-62.

82. Testa NN, Mazur KU. Hetreotopic ossification after direct lateral approach and transtrochanteric approach to the hip. Orthop Rev 1988; 17:965-71.

83. Ahrengart L, Lindgren U. Functional significance of heterotopic bone formation after total hip arthroplasty. J Arthroplasty 1989;4: 125-31.

84. Müller JP, Koch P. Periarticular ossification in total hip prostheses. Orthopäde 1989;18:511-6.

85. Hoikka V, Lindholm TS, Eskola A. Flurbiprofen inhibits heterotopic bone formation in total hip arthroplasty. Arch Orthop Trauma Surg 1990;109:224-6.

86. Kjaersgaard-Andersen P, Sletgård J, Gjerløff C, Lund F. Heterotopic bone formation after noncemented total hip arthroplasty: location of ectopic bone and the influence of postoperative antiinflammatory treatment. Clin Orthop 1990;252:156-62.

87. Gebuhr P, Soelberg M, Ørsnes T, Wilbek H. Naproxen prevention of heterotopic ossification after hip arthroplasty. Acta Orthop Scand 1991;62:226-9.

88. Wahlström O, Risto O, Djerf K, Hammerby S. Heterotopic bone formation prevented by Diclofenac. Acta Orthop Scand 1991;62: 419-21.

89. Reis HJ, Küsswetter W, Schellinger T. The suppression of heterotopic ossification after total hip arthroplasty. Int Orthop 1992;16: 140-5.

90. Nollen AJG, van Douveren FQMP. Ectopic ossification in hip arthroplasty: a retrospective study of predisposing factors in 637 cases. Acta Orthop Scand 1993;64:185-7. 